\title{
Haemolysis in experimental cholestasis: Possible role of erythrocyte sialic acid
}

\author{
LAWRIE W. POWELL ${ }^{1}$, J. THOMAS LAMONT, AND KURT J. ISSELBACHER \\ From the Departments of Medicine (Gastrointestinal Unit), Massachusetts General Hospital, and Harvard \\ Medical School, Boston, Massachusetts, USA
}

SUMMARY Because previous studies have suggested that red cell membrane sialic acid might be a determinant of survival in vivo, we examined the relationship between haemolysis, erythrocyte membrane sialic acid, and hepatic neuraminidase (sialidase) levels in experimental cholestatic jaundice in rats.

Treatment of normal rat erythrocytes with neuraminidase in vitro resulted in a significant reduction in their survival in vivo and removal by the spleen. The degree of haemolysis was comparable to that previously found 12 days after bile duct ligation in rats. Bile duct ligation resulted in a significant increase in hepatic neuraminidase and a decrease in erythrocyte sialic acid.

The findings are consistent with the hypothesis that one or more neuraminidases present in inreased amounts in the bile duct-ligated livers are responsible for the removal of sialic acid from circulating erythrocytes and subsequent removal of these cells in the spleen.

A shortened red cell survival is almost universal in liver disease but in most instances the pathogenesis is obscure (Pitcher and Williams, 1963; Kimber, Deller, Ibbotson, and Lander, 1965; British Medical Journal, 1969). Brisk haemolysis may occur in cirrhosis complicated by 'spurring' of erythrocytes (Cooper and Jandl, 1968), alcoholic fatty liver and hyperlipidaemia (Zieve, 1958), autoimmune haemolytic anaemia accompanying active chronic hepatitis or cirrhosis (Dacie, 1967), and haemolytic crises of Wilson's disease (McIntyre, 1967). Much more common, however, is the mild haemolysis which has been described in infectious hepatitis (Conrad, Schwartz, and Yound, 1964; Conrad, 1969), chronic hepatocellular or cholestatic jaundice (Pitcher and Williams, 1963), and experimental bile duct ligation in rats (Powell, Dunnicliff, and Billing, 1968). Cross-transfusion studies have suggested that the mechanism of this haemolysis involves an acquired red cell defect possibly due to a circulating plasma factor (Conrad, 1969; Pitcher and Williams, 1963; British Medical Journal, 1969) but direct evidence for such a factor is lacking.

1 Present address : Department of Medicine, Clinical Sciences Building, Royal Brisbane Hospital, Brisbane 4029, Queensland, Australia (to which reprint requests should be addressed).

Received for publication 30 April 1974.
Ashwell and Morell (1971) have recently shown that removal of sialic acid ( $\mathrm{N}$-acetylneuraminic acid, NANA) in vivo from many serum glycoproteins reduces their half-life in vitro. Removal of sialic acid from the surface of lymphocytes has been shown to alter their distribution in various organs (Woodruff and Gesner, 1969). It is also known that senescent red cells have reduced membrane sialic acid and a lower net surface charge as compared with young red cells (Greenwalt, Steane, and Pine, 1971). Because of the possibility that red cell membrane sialic acid might be a determinant of survival in vivo, we examined the relationship between haemolysis, erythrocyte membrane sialic acid, and hepatic neuraminidase (sialidase) levels in bile duct-ligated rats.

\section{Material and Methods}

EXPERIMENTAL CHOLESTASIS

Inbred adult male Fischer rats (Sprague-Dawley Co, Madison, Wisc) weighing between 200 and 250 grams were used in all experiments. Cholestatic jaundice was produced by dividing the common bile duct between two ligatures under light ether anaesthesia. The sham operation simulated this procedure closely except that the common bile duct was mani794 
pulated but not ligated or divided. All studies on these rats were performed between the fifth and seventh day after bile duct ligation.

MEASUREMENT OF RED CELL SURVIVAL AND ORGAN DISTRIBUTION

Red cell survival was performed using $\mathrm{Na}_{2}{ }^{51} \mathrm{Cr} \mathrm{O}_{4}$ as previously reported (Powell et al, 1968). Organ distribution of ${ }^{51} \mathrm{Cr}$ seven days after injection of labelled erythrocytes was determined by homogenizing the organs in 3 volumes of distilled water and counting aliquots in a Nuclear Chicago autogamma spectrometer. In experiments in vivo using neuraminidase, the ${ }^{51} \mathrm{Cr}$-labelled cells were suspended in $0.05 \mathrm{M}$ acetate buffer $\mathrm{pH} 5.0$ and incubated with varying quantitites of neuraminidase at $37^{\circ} \mathrm{C}$ for 30 minutes. The suspension was centrifuged at 1000 rpm for 10 minutes and the supernatant kept for sialic acid determination. The red cell pellet was then washed with $0.9 \% \mathrm{NaCl}$ and resuspended in this for slow intravenous injection. Each rat was reinjected with his own treated cells.

\section{NEURAMINIDASE TREATMENT OF RED CELLS}

FOR STUDIES 'IN VITRO'

Red cells were washed four times with $0.9 \% \mathrm{NaCl}$ or phosphate-buffered saline (PBS) and a 50\% suspension in $0.05 \mathrm{M}$ acetate buffer $\mathrm{pH} 5.0$ prepared. Red cell counts were performed using a ClayAdams counting chamber and each suspension was adjusted to a constant red cell count. The suspension was then incubated with varying concentrations of Vibrio cholerae neuraminidase (Behring Diagnostics) in acetate buffer for 30 minutes at $37^{\circ} \mathrm{C}$ in a water bath with gentle agitation. In control experiments neuraminidase, which had been inactivated by heating at $95^{\circ} \mathrm{C}$ for 30 minutes, was used. At 30 minutes the suspensions were immediately centrifuged at $1000 \mathrm{rpm}$ and the supernatant removed for sialic acid assay by the method of Warren (1959).

\section{RED CELL SIALIC ACID ASSAY}

Red cell ghosts were prepared by the method of Steck, Weinstein, Strauss, and Wallack (1970) and either treated with neuraminidase in acetate buffer as above or hydrolysed with $0 \cdot 1 \mathrm{~N} \mathrm{H}_{2} \mathrm{SO}_{4}$ to release sialic acid which was then measured in the supernatant. Protein concentration was determined by the method of Lowry, Rosebrough, Farr, and Randall (1951).

TISSUE AND PLASMA NEURAMINIDASE DETERMINATIONS

Liver homogenates were prepared from bile ductligated and sham-operated rats in $0.1 \mathrm{M}$ sodium acetate buffer, $\mathrm{pH} 4 \cdot 2$, in a $1: 4$ ratio $(\mathrm{w} / \mathrm{v})$. The suspensions were homogenized in a Waring blender at medium speed for 30 seconds. Neuraminidase activity in the previously frozen homogenates was measured by the direct method of Horvat and Touster (1968) using bovine sialyllactose (Calbiochem) $7 \mathrm{mg} / \mathrm{ml}$ as substrate (exogenous activity). Endogenous activity was measured in the absence of added substrate. Plasma neuraminidase was measured by the same method using undiluted plasma.

\section{GEL ELECTROPHORESIS OF RED CELL} MEMBRANE PROTEINS

Sodium dodecyl sulphate polyacrylamide $(8 \%)$ gel electrophoresis was performed by the method of Fairbanks, Steck, and Wallach (1971) on red cell ghosts prepared as described above.

\section{Results}

\section{RELEASE OF RED CELL SIALIC ACID BY} NEURAMINIDASE

The amounts of sialic acid released by incubating normal rat erythrocytes with increasing amounts of neuraminidase are shown in figure 1 . Under the experimental conditions described there was a linear relationship up to 50 units neuraminidase $/ \mathrm{ml}$ and the maximum quantity of sialic acid released was $10.9 \mu \mathrm{g} / 10^{9}$ cells. That the neuraminidase had no significant proteolytic effect on the red cell membrane was shown by SDS electrophoresis of red cell ghosts (fig 2). There were small quantitative but no significant qualitative differences between the major protein bands of cells treated with neuraminidase compared with control cells treated with heatinactivated enzyme.

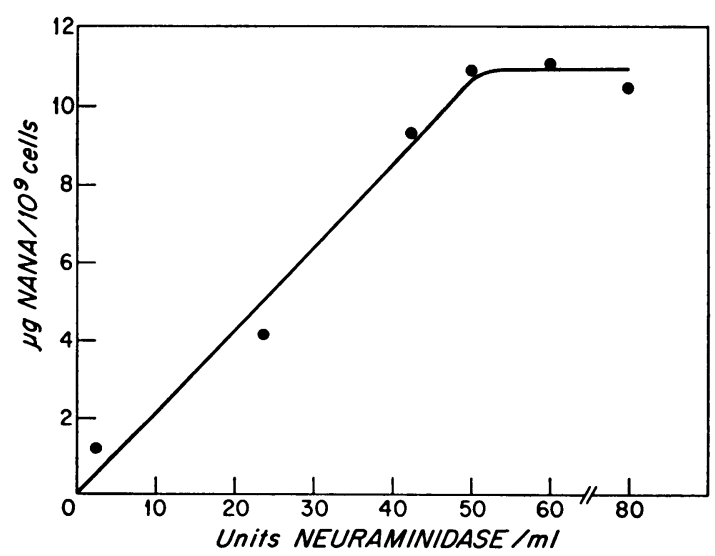

Fig 1 Release of sialic acid from normal rat erythrocytes by increasing amounts of Vibrio cholerae neuraminidase under the experimental conditions described in the text. 
A

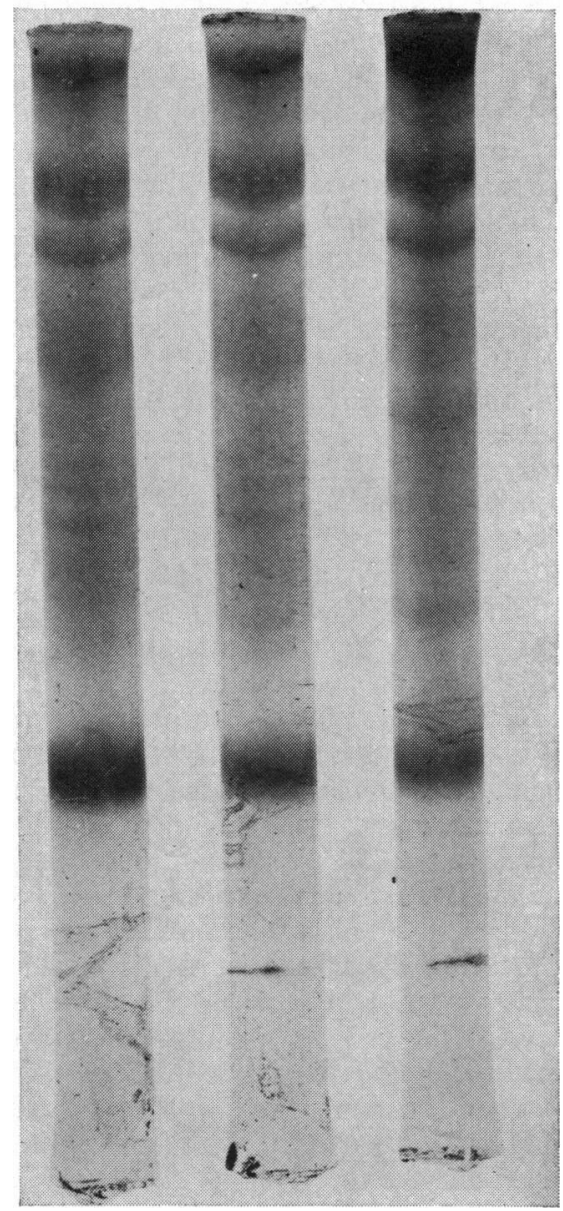

Fig 2 SDS electrophoresis of red cells ghosts prepared after treatment of intact erythrocytes with neuraminidase. Left: $50 \mu / \mathrm{ml}$ neuraminidase; middle: $80 \mu / \mathrm{ml}$; right: inactivated neuraminidase $50 \mu / \mathrm{ml}$. There were small quantitative differences between the protein bands but no qualitative differences.

SURVIVAL IN VIVO AND ORGAN DISTRIBUTION OF ERYTHROCYTES TREATED WITH

NEURAMINIDASE

Figure 3 shows the effect of neuraminidase treatment on the survival in vivo of rat erythrocytes. With increasing concentrations of neuraminidase there was a progressive release of sialic acid from the erythrocytes and a progressive decrease in erythrocyte survival. The reduction in red cell survival reached statistical significance with $1.0 \mathrm{U} / \mathrm{ml}$ of neuraminidase $(t=3.72, P<0.01)$ and the difference between all treated groups taken together and control animals was highly significant $(t=5 \cdot 25$,

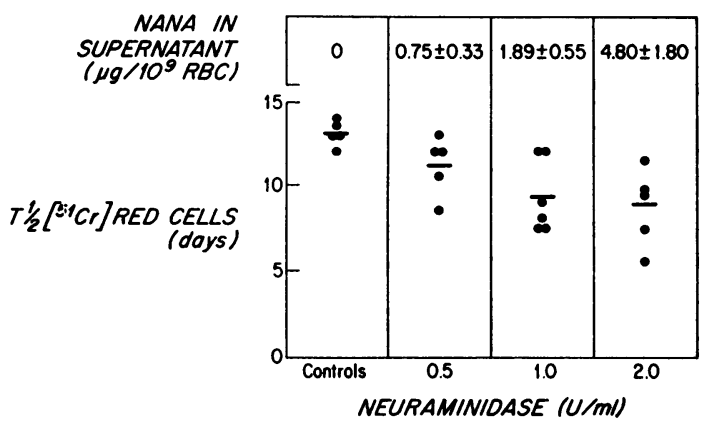

Fig 3 Survival in vivo of rat erythrocytes after treatment in vitro with neuraminidase.

$P<0.001)$. The neuraminidase was shown to have no effect on ${ }^{51}$ chromium labelling of the erythrocytes. Studies of organ distribution (fig 4) of ${ }^{51} \mathrm{Cr}$-labelled erythrocytes seven days after injection revealed a significant increase in uptake by the spleen in the neuraminidase-treated group $(t=3.54 ; P<0.01)$. Hepatic uptake was slightly increased in the neuraminidase-treated group but the difference was not statistically significant.

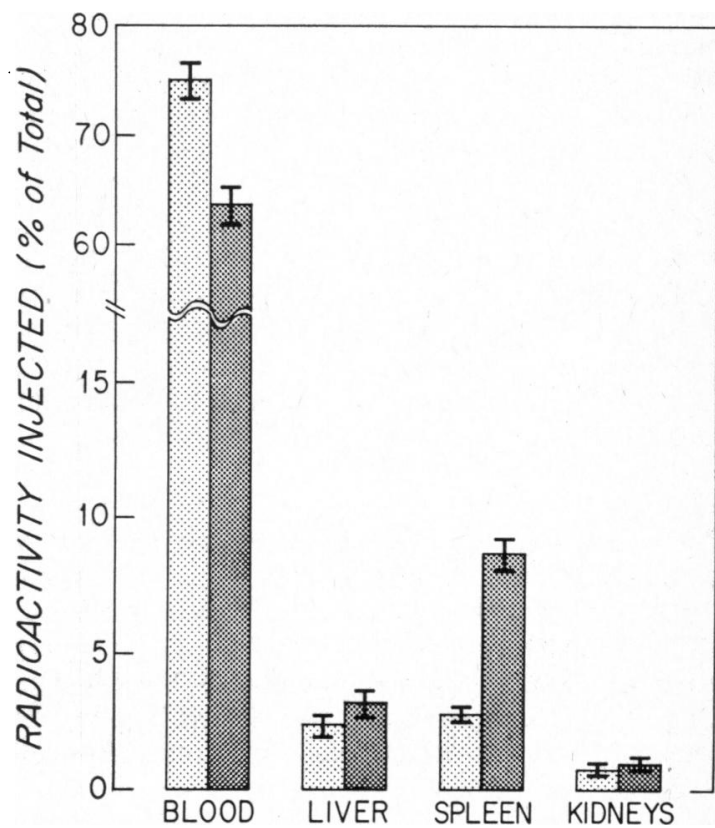

Fig 4 Organ distribution (mean $\pm S E M$ ) of ${ }^{51} \mathrm{Cr}$ seven days after injection of neuraminidase-treated and control erythrocytes labelled with ${ }^{51} \mathrm{Cr}$. Lightly stippled bars: controls, heavily stippled bars: neuraminidasetreated $(2 \cdot 0 \mathrm{U} / \mathrm{ml})$ cells. 
SIALIC ACID CONTENT OF RED CELLS FROM

BILE DUCT-LIGATED AND CONTROL RATS

The amounts of sialic acid removed from normal erythrocytes and from those of bile duct-ligated animals after treatment with neuraminidase (50 $\mathrm{Ug} / \mathrm{ml}$ ) were $8.38 \pm \mathrm{SD} 1.2$ and $6.59 \pm \mathrm{SD} 0.8 \pm$ $\mu \mathrm{g} / 10^{9}$ cells respectively $(\mathrm{t}=2.53 ; \mathrm{P}<0.05)$. The amount of sialic acid released from control erythrocytes was slightly lower in this experiment than in the experiment shown in figure 1. This may have been due to minor differences in experimental conditions and activity of the neuraminidase preparations since the experiments were performed on different occasions.

\section{TISSUE AND PLASMA NEURAMINIDASE}

\section{ACTIVITY}

Figure 5 shows the neuraminidase activity in liver

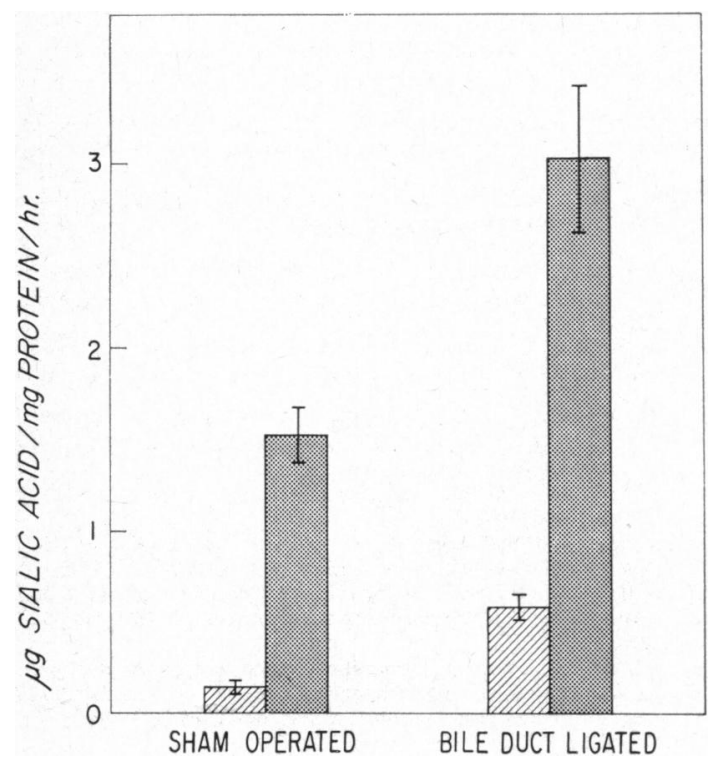

Fig 5 Neuraminidase activity (mean $\pm S E$ ) in liver homogenates from sham-operated and bile duct ligated rats. Cross hatched bars: endogenous neuraminidase activity; Stippled bars: exogenous activity (see text).

homogenates from bile duct-ligated and control rats. Both the endogenous activity, which represents removal of sialic acid from glycoproteins and glycolipids within the liver homogenates, and the exogenous activity using sialyllactose as substrate, were significantly greater in the livers of bile duct-ligated rats. We were unable to demonstrate significant neuraminidase activity in the plasma of bile ductligated or control rats using sialyllactose as substrate.

\section{Discussion}

The results of this study demonstrate that mild treatment of rat erythrocytes with Vibrio cholerae neuraminidase results in a significant decrease in red cell survival. Furthermore it would appear from these results that removal of only $17 \%$ of total membrane sialic acid is required to effect this decrease in erythrocyte survival. Similar though more severe haemolysis was produced by Gilcher, Glader, and Conrad (1970) and Gilcher and Conrad (1971) by treating rat erythrocytes with neuraminidase. These investigators found that treated erythrocytes were less easily deformed and were removed by the spleen and liver. They concluded that the haemolysis resulting from neuraminidase treatment was due to reduction in cell surface charge and the consequent decreased liability for the cells to be deformed and increased removal by the reticuloendothelial system.

The degree of reduction of red cell survival found in the present study using neuraminidase was comparable to that resulting from bile duct ligation in rats. Powell et al (1968) showed that bile duct ligation resulted in a reduced red cell survival from a $T_{\frac{1}{2}}$ of 13.4 days to eight days in Sprague-Dawley rats and from 15.5 to 5.5 days in Wistar rats. In these experiments the red cell survival studies were begun 12 days after bile duct ligation. A further decrease in survival was demonstrated 28 days after bile duct ligation.

Neuraminidase treatment has also been shown to reduce the half-life of serum glycoproteins by enhancing hepatic removal. Ashwell and Morell (1971) have shown that removal of 15 to $25 \%$ of sialic acid from caeruloplasmin resulted in a markedly decreased plasma half-life. These workers have further shown that exposure of a galactose moiety on the glycoprotein side chains is the key determinant in enhanced hepatic clearance. The mechanism of removal of desialated serum glycoproteins has recently been postulated to involve a galactosyltransferase enzyme on the cell surface of the hepatocyte which binds to the exposed galactose residue of the glycoprotein (Aronson, Tan, and Peters, 1973). Whether removal of erythrocytes by the reticuloendothelial system involves similar molecular mechanisms is currently unknown.

Our findings of an increase in liver neuraminidase and decrease in erythrocyte sialic acid in bile duct ligated rats are consistent with the hypothesis that one or more neuraminidases present in increased amounts in the bile duct ligated livers are responsible for the removal of sialic acid from circulating erythrocytes and subsequent removal of these cells in the reticuloendothelial system, predominantly in the spleen. Neuraminidase in mammalian liver is located 
primarily in plasma membranes and lysosomes (Horvat and Touster, 1968; Schengrund, Jensen, and Rosenberg, 1972). It is possible that with the gross structural alterations and cell necrosis which result from bile duct ligation, circulating red cells may come in close contact with hepatocyte plasma membranes and lysosomes or with neuraminidase released from these subcellular organelles. Our failure to demonstrate neuraminidase activity in the plasma of normal or bile duct-ligated rats may indicate that the enzyme is destroyed or inhibited soon after its release into the circulation. It is noteworthy that other investigators have been unable to demonstrate neuraminidase in mammalian plasma unless large volumes were first purified, presumably removing an inhibitor (Warren and Spearing, 1960).

Thus, this study has shown that bile duct ligation in rats results in a pronounced increase in liver neuraminidase and a significant reduction in red cell sialic acid, which is responsible for red cell surface change and liability to become deformed. Further, neuraminidase treatment of red cells in vitro releases surface sialic acid and results in a decreased red cell survival in vivo. Whether these observations are pertinent to the pathogenesis of the haemolysis associated with human liver disease will require similar studies in jaundiced patients.

\section{References}

Aronson, N. N., Jr., Tan, L. Y., and Peters, B. P. (1973). Galactosyl transferase-the liver plasma membrane binding site for asialo-glycoproteins. Biochem. biophys. Res. Commun., 53, 112-118.

Ashwell, G., and Morell, A. G. (1971). Galactose: a cryptic determinant of glycoprotein catabolism. In Glycoproteins of Blood Cells and Plasma, edited by G. A. Jamieson and T. J. Greenwalt, pp. 173-189. Lippencott, Philadelphia.

British Medical Journal (1969). Leading article. Haemolysis in hepatitis and jaundice. Brit. med. J., 4, 637-638.

Conrad, M. E. (1969). Persistent haemolysis after infectious hepatitis. Gut, 10, 516-521.

Conrad, M. E., Schwartz, F. D., and Yound, A. A. (1964). Infectious
hepatitis-A generalized disease. A study of renal, gastrointestinal and hematologic abnormalities. Amer. J. Med., 37, 789801.

Cooper, R. A., and Jandl, J. H. (1968). Bile salts and cholesterol in the pathogenesis of target cells in obstructive jaundice. J. clin. Invest., 47, 809-822.

Dacie, J. V. (1967). In The Haemolytic Anaemias, 2nd ed., Vol. 3, pp. 836-7. Churchill, London.

Fairbanks, G., Steck, T. L., and Wallach, D. F. H. (1971). Electrophoretic analysis of the major polypeptides of the human erythrocyte membrane. Biochemistry, 10, 2606-2617.

Gilcher, R., and Conrad, M. (1971). The relationship of red blood cell surface change to red blood cell deformability. In Proceedings of the 14th Annual Meeting of the American Society of Hematology, p. 49.

Gilcher, R., Glader, B., and Conrad, M. (1970). Reticuloendothelial recognition and hemolysis of red blood cells with reduced surface change. Proceedings of the 13th Annual Meeting of the American Society of Hematology, p. 55.

Greenwalt, T. J., Steane, E. A., and Pine, N. E. (1971). Changes in erythrocyte surface antigens with aging in vivo. In Glycoprotein of Blood Cells and Plasma, edited by G. A. Jamieson and T. J. Greenwalt, pp. 235-244. Lippencott, Philadelphia.

Horvat, A., and Touster, O. (1968). On the lysosomal occurrence and the properties of the neuraminidase of rat liver and of Ehrlich ascites tumor cells. J. biol. Chem., 243, 4380-4390.

Kimber, C., Deller, D. J., Ibbotson, R. N., and Lander, H. (1965). The mechanism of anaemia in chronic liver disease. Quart. $J$. Med., 34, 33-64.

Lowry, O. H., Rosebrough, N. J., Farr, A. L., and Randall, R. J. (1951). Protein measurement with the folin phenol reagent. $J$. biol. Chem., 193, 265-275.

McIntyre, N., Clink, H. M., Levi, A. J., Cumings, J. N., and Sherlock, S. (1967). Hemolytic anemia in Wilson's disease. New Engl. J. Med., 276, 439-444.

Pitcher, C. S., and Williams, R. (1963). Reduced red cell survival in jaundice and its relation to abnormal glutathione metabolism. Clin. Sci., 24, 239-252.

Powell, L. W., Dunnicliff, M. A., and Billing, B. H. (1968). Red cell survival in experimental cholestatic jaundice. Brit. J. Haemat., $15,429-435$.

Schengrund, C. L., Jensen, D. S., and Rosenberg, A. (1972). Localization of sialidase in the plasma membrane of rat liver cells. J. biol. Chem., 247, 2742-2746.

Steck, T. L., Weinstein, R. S., Straus, J. H., and Wallach, D. F. H. (1970). Inside-out red cell membrane vesicles: preparation and purification. Science, 168, 255-257.

Warren, L. (1959). The thiobarbituric acid assay of sialic acids. J. biol. Chem., 234, 1971-1975.

Warren, L., and Spearing, C. W. (1960). Mammalian sialidase (neuraminidase). Biochem. biophys. Res. Commun., 3, 489-492.

Woodruff, J. J., and Gesner, B. M. (1969). The effect of neuraminidase on the fate of transfused lymphocytes. J. exp. Med., 129, 551-567.

Zieve, L. (1958). Jaundice, hyperlipemia and hemolytic anemia: a heretofore unrecognised syndrome associated with alcoholic fatty liver and cirrhosis. Ann. intern. Med., 48, 471-496. 